Article

\title{
Star Wars: The Last Jedi, Beauty and the Beast, and Disney's Commodification of Feminism: A Political Economic Analysis
}

\author{
Kailash Koushik and Abigail Reed * \\ School of Communication, Florida State University, 3100 University Center, Building C, Tallahassee, FL 32306, \\ USA; kk15h@my.fsu.edu \\ * Correspondence: a.reed@fsu.edu
}

Received: 1 October 2018; Accepted: 28 October 2018; Published: 15 November 2018

\begin{abstract}
This paper seeks to explore the strategies Hollywood utilizes to capitalize on feminist social movements through replacing hegemonic male characters with female ones or updating traditional stories through a more "feminist" retelling. By analyzing both 2017's Star Wars: The Last Jedi and Beauty and the Beast as representative of this corporate trend, we critique the ways in which these pseudo-feminist texts not only contribute little to the social conversation surrounding the evolving roles of women and their representations in media through the lenses of critical political economy, feminist political economy, and feminist film criticism. We conclude that creating "feminist" reimaginings of classic narratives ultimately serves to uphold the existing economic structures that maintain social and financial capital within the largest Hollywood studios. Thus, little to no social progress is made through the creation of these retellings.
\end{abstract}

Keywords: Disney; gender; feminism; political economy of film; feminist film criticism; feminist political economy of media

\section{Introduction and Literature Review}

In 2017, Hollywood saw two contradicting trends. On one hand, it was rocked by sexual harassment and abuse scandals, with women coming forward and revealing not only the names of their abusers, but also the rampant prevalence of such harassment. Along with unequal pay/remuneration in Hollywood between men and women, this scandal brought to light the dismal working conditions of women in Hollywood. On the other hand, the top three box office hits in America-Star Wars: The Last Jedi, Beauty and the Beast, and Wonder Woman-were all movies with women in lead roles. Following the trend of movies such as Hidden Figures and Ghostbusters, and paving the way for movies such as Ocean's 8, which has an all-woman cast, along with movements such as \#meToo and Time's Up, Hollywood is positioning itself to be championing the causes of women by producing films with women as protagonists. Instead of simply celebrating this trend, there needs to be a critical evaluation of it, lifting the curtains and looking behind the screen to analyze the political economy of these movies and whether or not they truly empower oppressed groups.

Disney's unique claim on the cultural marketplace both in the U.S. and worldwide makes studying this trend important as it has vast ramifications for smaller cultural producers and the public discourse at large. A 2006 study of the worldwide cultural reach of Disney's intellectual property highlights how widespread and integrated Disney characters and narratives are in global culture (Wasko et al. 2006). Thus, detailed examinations of contemporary media produced by Disney have great significance as they are disseminated into our shared global media culture. Furthermore, Star Wars: The Last Jedi and Beauty and the Beast are significant not only because of their status as two of the top three highest 
grossing films worldwide in 2017, but because they are emblematic of Disney's growing tendency to commodify the core tenants of social movements and repackage them in a fashion better suited to their global market interests. In the interest of exploring the specific ways in which this is done, this analysis is positioned at the intersection of feminist film criticism, political economy of film, and feminist political economy of media. By utilizing these methodologies and approaching the films from a critical perspective, Disney's commodification of feminist movements are highlighted. Specific examples of this are analyzed in the narratives of both the films, as well as details from their production, to underscore that these texts are not made to empower the audience; rather, they are made to sell merchandise.

\subsection{Methodologies}

Political Economy of Film. The political economy of media is defined as "the study of social relations, power relations in particular, that mutually constitute the production, consumption, and distribution of resources, in particular communication resources" (Hardy 2014; McChesney 2008; Mosco 2009). The political economy of film focuses on production, consumption, and distribution of films and how the mode of production influences the content of specific movies (Wasko 2003). In most parts of the world, and certainly in the United States, films are produced and consumed within a capitalist mode of production, in which films are produced for sale, with the intent to earn profit (Mirrlees 2013). Within this system, it is important to understand films as commodities, which exist both as a material commodity and as a service, being exchanged in the capitalist economy (Pendakur 1990, p. 39).

In the current age of global transnational capitalism and a New International Division of Cultural Labour (NIDCL), the production, distribution, and consumption of Hollywood movies occur with inputs of resources from around the world, ranging from investments and shooting locations to cultural labor, changing the once existent flow of movies produced only in Western countries and exported to other parts of the world (Miller et al. 2005). This shift in production has decentralized the filmmaking process and spread it across the world, creating an illusion of Hollywood diluting its hold over film production.

The shift, however, has not reduced the domination of Hollywood. Nonetheless, the US movie industry is constantly trying to capture a larger global market with films worth US\$ 16.3 billion exported during 2014 alone (Robb 2016). The current global capitalist landscape or the global distribution of production processes have not altered the concentrated ownership in Hollywood either. Hollywood still remains an oligopolistic monopoly, with a few transnational companies dominating the film industry: Disney, Time Warner, Viacom, Comcast, News Corporation, and Sony [GE sold NBC to Comcast] (Baker 2013; Hardy 2014). These corporations are not just involved in film production, but all aspects of distribution and exhibition. For example, The Walt Disney Company has operations in TV media networks, entertainment parks, studios, and consumer products (Walt Disney Company 2017). To illustrate further, out of the top 20 highest grossing movies in 2017, six were produced by Disney, while Time Warner, Comcast and Viacom produced the rest (Box Office Mojo 2017).

Synergy, integration, and intellectual property rights allow these companies to dominate the market. These companies are integrated horizontally and vertically, allowing them complete control over the production process, from the conception of a movie, the theaters at which it is shown, other distribution markets, to any merchandise sold based on the movie (Croteau and Hoynes 2006; Hardy 2014). The presence of this kind of control over all aspects of production makes these studios financially favorable to investors, as there will be opportunities for lending money in exchange for ownership of shares or copyrights (Bettig and Hall 2012). These companies are able to lure investors with incentives like partial ownership of copyrights, because they also own the rights for the movie produced (Bettig and Hall 2012). These transnational conglomerates control and own marketing firms and other media, allowing them to promote their films not just domestically, but also globally (Bettig and Hall 2012). To further the Disney illustration, Disney can produce a movie in its studios, 
promote it on its TV networks, produce merchandise, stream the same in its interactive media, and build rides based on the same in its entertainment parks. Transnational media conglomerates like Disney are in possession of the resources that enable them to distribute and promote their movies globally, ensuring its success due to its control of global movie distribution (Gomery 2004, p. 194).

Under these conditions of the production and distribution of films, political economy reveals structural inequalities in such flows, combining it with an analysis of larger influences on production and distribution, considering the polyvalency of texts such as film within ideological boundaries (Hardy 2014, p. 167). It peels off the layers of the celebration of the success of Hollywood to reveal how the conditions of the mode of production influence the film process and its implications on socio-political aspects of society (Wasko 2003).

One of the main motivations under the capitalist mode of production is the maximization of profit. Transnational media companies constantly engage in production activities that achieve the largest amount of profits and the lowest levels of risk. The creation of sequels is one of the ways this can be achieved. Creation of synergistic entertainment franchises ensure a steady stream of movies that depend upon a pre-constituted audience, who ensure not just the consumption of the media text, but also consumption of merchandise related to the franchise (Proffitt et al. 2007; Meehan 2005). Mirrlees (2014) provides a detailed explanation of how these sequels most often have a "globally popular design" ensured to attract not just a pre-constituted audience, but also general populations globally. Studios also cast famous actors, hire famous directors, and recycle older versions of a film motivated by the same logic of maximizing profits, resulting in a constant recycling, repackaging, revisioning, and recirculating of films (Meehan 2005). Consequently, studios also bring out merchandise, video games, and collaborate with other companies such as fast food companies and sport franchises to constantly engage the audience not only within the theater, but also in everyday activities, creating an audience guaranteed to consume prequels, sequels, live action animation and the like (Jess-Cooke 2009).

Political economy, then, deals with the question of who controls film and media, and how such a structure influences the production of content. Consequently, for political economy of media, power, and the analysis of power in society, becomes central to the theory's rationale (Hardy 2014). It examines the interrelations between power, wealth, and knowledge (Norris 1990). In such an attempt to understand power in society, issues of gender become significant.

Feminist Political Economy of Media. Analyzing the ways in which narratives and ideologies that are oppressive toward women function in the production and consumption of films requires adding a feminist theory perspective onto a political economic view of film and the culture industry at large. This article uses the ideology of socialist feminism, in conjunction with feminist political economy, as the most natural position from which the two frameworks coincide (Steeves and Wasko 2002). A feminist political economic methodology seeks to enhance analyses and criticisms of the power structures present within economies and financial structures with a theoretical lens that highlights how women are specifically marginalized within these structures according to their gender (Rai and Waylen 2013). Broadly speaking, feminist political economy, "presents ways to move away from conceptualizing political economy as only looking at labor or class relations in order to broaden our understanding of accumulation and the reproduction of capitalism" (Riordan 2002, p. 7). Meehan (2005) also provides a feminist perspective of political economy, wherein she views the same problems of the capitalist market with the lens of gender. The ideologies that naturalize the oppression of women also shape the corporate decisions taken at all points of production and consumption of a movie (Meehan 2005). When examining any piece of media from a critical lens, it is especially important to engage with its ideological assumptions and implications regarding marginalized populations. Because the two films being analyzed in this article are marketed toward women and girls and deliberately include "progressive" representations of women, it is essential to integrate a multidimensional critical perspective. 
Feminist Film Criticism. Furthermore, the tradition of feminist film criticism is invoked in order to facilitate a nuanced understanding of the way in which female characters are presented in both Beauty and the Beast and The Last Jedi. The aim of this essay is to problematize and to "look back" at the narratives of women that contemporary corporate Hollywood is presenting to a global audience. Laura Mulvey began doing this when she theorized that men exercised their scopophilia and the desire to objectify women by going to the cinema and, conversely, women experienced the sensation of "to-be-looked-at-ness" (Mulvey 1975). The cinema was thus a place for men and male fantasy and women were constructed to be the object of this cinematic fantasy. Linda Williams takes this idea further in a detailed examination of films within the horror genre and the construction of the female horror victim as a figure of pleasure for the male spectator (Williams 1984). She challenges the reader (specifically the female reader) to examine the films critically and trouble their representation of "free sexuality" at the cost of violence against the female body. In other words, Williams challenges the female audience to gaze back at the very film that is objectifying them.

Contemporary feminist film criticism has expanded from this core mission to integrate a more interdisciplinary approach. Queer theory, critical race studies, disability studies, and political economy have all been coalesced into the larger body of literature to address issues of marginalization within cinema. This article aligns itself with a feminist political economic approach that harkens back to the philosophical assumptions that feminist film criticism was built upon in the 70s and 80s. Bringing a political economic perspective into film criticism serves to question the structural existence of Hollywood and problematize the way in which films are created and how audiences are meant to enjoy them. Specifically, the political economy of film, feminist political economy, and feminist film criticism will be used to peel the layers off the success and celebration of Star Wars: The Last Jedi and Beauty and the Beast as "triumphantly feminist films" and interrogate their position in relation to contemporary feminism.

\subsection{The Gendered Commodity Market}

Meehan (2002) outlines how media companies have progressively changed their content creation and advertising strategy from targeting the "universal" market of white men aged 18-34 to pinpointing certain niche markets that were not being catered to (such as women who stayed home during the day and watched television) (Meehan 2002, p. 217). What is occurring in the current media landscape, and specifically with the Star Wars franchise, is that texts created for the "universal" white male 18-34 audience are being recreated with specific attention paid to niche markets (particularly women) and specific elements of the narratives and the marketing strategy are catered to the niche market, while the media product as a whole is still created for the "universal" audience. An example of this is the HerUniverse clothing line that was created for female fans of the Star Wars franchise in order to capitalize on that commodity market, whereas before Star Wars themed clothing was marketed toward male consumers. However, instead of using this space created for female fans to destabilize gender norms, the goods sold rely on classic princess tropes that reify traditional gendered stereotypes (Johnson 2014).

The princess line of dolls released by Disney includes Belle from The Beauty and the Beast, which was described by Variety, as "a global marketing machine shrewdly designed to accessorize young girls with all the sparkly merchandise their little hearts desire" (quoted in Bettig and Hall 2012, p. 213). Beauty and the Beast had $60 \%$ female audience members in its opening weekend with industry reporters attributing it to the "feminist DNA" of the movie (Lang 2017). But since 2009, Belle was marketed exclusive to young girls through the princess merchandise line.

As Meehan observes, in this economic environment that focuses on niche audiences, media content is not truly what is being created. Referencing Smythe (1977), she states: "the media manufactured only one commodity-audiences. By this, Smythe meant that all media assembled, packaged, and sold audiences to advertisers. Content was secondary-a free lunch at best" (Meehan 2002, p. 211). Because content is secondary to the commodity markets being built (specifically the gendered commodity 
market), it is all the more important to examine how gender is being deployed both within the world of the film and in our own world (specifically in the content of the contemporary discourses of neoliberalism, postfeminism, and commodity feminism; which will be addressed in the discussion section), as both serve the primary purpose of selling goods to audiences.

\subsection{Merchandise Market}

Merchandising, and Disney princesses in particular, remains a strong source of revenue for Disney, with annual sales of Disney princess merchandise averaging at around US\$4 billion in 2016-2017 (Barnes 2017). Star Wars in particular has long been in the news for the sale of its merchandise. Toys $\mathrm{R}$ Us sold 1.25 million units of The Phantom Menace merchandise in 1999, with sales averaging US\$150,000 in the first three and a half hours in their New York City flagship store. The prediction about the "biggest event in the history of toy history," was between US\$500 million to a billion by the end of 1999. Apart from this, the movie also had tie ins with fast food joints and fantasy novels (Jensen 1999). The trend remained similar for The Force Awakens and Rogue One, but slightly weakened for The Last Jedi. In 1999, merchandising was not available until the day before the movie was released (Jensen 1999). However, Disney opened merchandising three months before The Force Awakens in 2015, and for The Last Jedi in 2017 (Townsend 2018). Although sales of merchandising was successful in 2015, this backfired in 2017. According to the CEO of Hasbro Inc, this was due to the three-month time period, which was difficult to maintain interest in the customers (Townsend 2018). Star Wars toys were still top selling during the holiday season of 2017, even though sales fell in comparison to the previous film in 2016 (Palmeri and Townsend 2017).

Disney has stumbled in its offerings of merchandise featuring major female characters in the Star Wars universe. Upon the release of 2015's The Force Awakens, consumers quickly noticed the widespread lack of Daisy Ridley's Rey in the new merchandise. Even in packages of action figures of the main characters in the new film, Rey, the primary main character, was not featured. This led to the \#WheresRey movement on social media platforms. Customers asked Disney why Rey was excluded from the new wave of toys if she was the main character of the new trilogy, particularly since Star Wars has historically had such a robust presence in the toy aisle (Scott 2017).

Although sales numbers are not available for Beauty and the Beast merchandise, analysts believe the movie to be a merchandising powerhouse, capable of targeting consumers from two different generations: the young adults who grew up with the animated $1991 \mathrm{film}$, and the next generation watching the live action movie for the first time (Davis 2017). Hasbro Inc. reported that Disney princesses as a whole were strong in 2017, but the top seller was Belle from Beauty and the Beast, and the company expected her to remain on top due to the success of the movie (La Monica 2017).

\subsection{Gender and the Remaking of Old Narratives}

Hegemonic gender stereotypes can be found throughout the Star Wars universe, including the toys, films, video games, novels, and beyond. George Lucas, original creator of the franchise, often cites Joseph Campbell's 1949 text, The Hero with a Thousand Faces, as being of prime importance when he was formulating the Star Wars mythos (Mythic Discovery 2015). Campbell sought to establish a universal human monomyth that explained the classical "hero's quest" narrative that is commonly found in disparate cultures throughout time by establishing certain archetypes that are typically adhered to in these myths. When setting out to create Star Wars, Lucas sought to create a hero's story largely devoid of culturally specific marks. However, Campbell's conception of the universal hero's journey is one that is decidedly male (Larabee 2016). This mythic template works when dealing with male protagonists such as Luke or Anakin Skywalker (the main characters of the Original and Prequel trilogies, respectively, who are responsible for both the ruin and the restoration of the galaxy) who nicely fit into hegemonic male gender confines. However, things become far more complex when you introduce a female character as the hero, as is the case with Rey in the Disney films. How does Rey fit into this classical "universal" mythos that Campbell theorized, one that has been made for men 
and maintained by men (both within the fictional and the real world) (Larabee 2016)? This is further complicated upon analysis of the Skywalker Saga's central hero/villain: Anakin (also known as Darth Vader). In fact, it has been argued that Anakin, by his alignment with Trujillo's (1991) six characteristics of hegemonic masculinity (which include physical force, control, occupational achievement, familial patriarchy, frontiersmanship, and heterosexuality), is freed from the responsibility of his actions; clearing the path for his redemption at the end of this life, which is shown at the end of 1983's Return of the Jedi (Atkinson and Calafell 2009, p. 2). It is debatable (and yet to be seen) whether or not a female protagonist will be afforded these same allowances within this mythos.

Just as Disney is attempting to update Star Wars with more female characters to capitalize on female consumers, it is diving into its old filmography and rethinking their old fairy tale classics. On 13 April 2017, Disney announced that its live action animation remake of The Beauty and the Beast grossed US $\$ 1.0024$ billion worldwide, making it Disney's 14th film to cross the billion-dollar mark (Mendelson 2017). The movie has a star cast with Emma Watson playing Belle, Dan Stevens as the Beast, and Luke Evans playing Gaston (Barnes 2017). The movie followed in Disney's tradition of remaking old films with new technology and star casts, with live action filmmaking combined with digitally created characters and backdrops, pushed to such an extent that the character of the Beast himself was full digitized, using motion sensors placed on Dan Stevens' face (Barnes 2017). This retelling of the same story, using new technology, provides an illusion that Disney is producing something revolutionary, but is really old wine in a new bottle.

Disney's strategy of swapping the gender of the primary protagonist in the new Star Wars films in order to connect with a young female consumer base is not completely unsimilar from the strategy it used to update Beauty and the Beast. Both narratives have very old roots in traditional mythology. Additionally, Beauty and the Beast already benefited from having a main female protagonist. Thus, Disney was able to change key characteristics about Belle in order to make her appear more "feminist" according to contemporary standards.

\section{Analysis}

\subsection{Making Star Wars Great Again}

When The Force Awakens was being promoted, some fans were in an uproar about the gender and race of two of the new protagonists. Star Wars, in the popular imagination, has always been a boy's story (more specifically, a white boy's story) and changing this hallowed tradition is sacrilegious according to some fans of the franchise. This combined with the betrayal and distrust that many Star Wars fans have of those in charge of the franchise (a topic that will be returned to) created a toxic environment within which Rey was debuted to the world. This is the stage for the premiere of 2017's The Last Jedi, which has a critical score of $91 \%$ and an audience score of $47 \%$ on Rotten Tomatoes (Star Wars: The Last Jedi 2017). Why is there such a vast discrepancy between these two groups of people? This depends on who is asked. Some credit the "alt-right" for hijacking both the Rotten Tomatoes audience score and the online discourse surrounding the film because of their self-professed dislike of the incorporation of female protagonists (Sharf 2017). There are countless think pieces revolving around the issue of gender in the film (Barsanti 2018; Florio 2017; Gertrude 2018; Gonzalez 2018; Moore 2017; Robinson 2017; Smith 2017; Weekes 2017; Why the Last Jedi Isn't just Bad: It's Toxic 2017), highlighting the stark divide in the audience between some who think the text offers a positive, progressive representation of women and those who think that women are best left out of meaningful roles in the franchise.

An Old Plot Made New? In The Last Jedi, Rey's journey as a fledgling Jedi Knight leads her on an expedition to find Jedi Master Luke Skywalker who is in hiding after the failure of his new Jedi Order. Luke reluctantly agrees to train Rey, but only in the interest of demonstrating to her why the Jedi need to be extinct. Simultaneously, fighter pilot Poe Dameron and General Leia Organa are continuing the Resistance's struggle with the fascist First Order, culminating in a battle that positions their small 
armada (all that remains of the fight against totalitarianism in the galaxy) against the First Order. Leia is injured in the battle and unable to continue acting as a general. Thus, Vice Admiral Holdo takes over and clashes with Poe over military strategies, leading him to enact a coup against her. As this occurs, Rey's training with Luke leads her to confront Kylo Ren, second-in-command of the First Order, himself a former student of Luke, and his nephew. Together, Kylo and Rey defeat Snoke, Supreme Leader of the First Order, leading Kylo to offer Rey a position next to him as rulers of the galaxy. Rey rejects his offer, solidifying the conflict between them. The film's third act ends with the separate narrative threads colliding in a final battle on the planet Crait wherein Kylo attempts to kill Luke but is unable to, and Rey rescues the remaining Resistance members. At the end of the film, Luke disappears (presumably becoming one with the Force) due to the effort of telekinetically projecting himself onto Crait from his remote hiding location on the planet Ahch-To.

Rey, General Leia, and Vice Admiral Holdo all hold positions of power within the narrative. Rey is positioning herself to become a Jedi as well as a leader in the Resistance. Leia is a well-established leader in both the military and political spheres. Holdo has an impressive record as a military commander. As more public pressure is put on Hollywood to both make the men who act in damaging ways accountable and to produce more progressive narratives, the female characters in The Last Jedi do seem to be a reaction to this culture change. Furthermore, one can see that the filmmakers are purposefully crafting a message that is friendly to a broader market so that the commodity market of young female consumers can also be targeted alongside the young males who make up the traditional audience for Star Wars. This aligns with Meehan's conception that media-makers attempt to acknowledge the market power of female consumers by establishing the "niche" gendered commodity audience, while keeping them seperate from "the" audience of white males ages 18-34 (2002). Hence, the narrative of The Last Jedi attempts to craft female characters that are conducive to marketing campaigns aimed at female consumers while keeping the film relevant to their primary audience of young male consumers.

Above all, Disney is a company interested in building branded, family-friendly entertainment that has widespread appeal. It is (mostly) not in the business of pushing boundaries or creating ground-breaking characters who stray far from the established norms of traditional gender representation, as is made apparent by a cursory glance through its classic film library (Cinderella, Sleeping Beauty, The Little Mermaid, etc.). This is also true in Disney's Star Wars films. While it has recognized that there is a large female fan base ready to spend money on the franchise and has begun to create content (both textually and extra-textually) to cater to that audience (Johnson 2014; Scott 2017), it has not fundamentally changed the structure of Star Wars from Lucas' vision modeled after the Joseph Campbell monomyth thesis. This would not be problematic if the series were not created to mimic a narrative structure created specifically for the male hero (Larabee 2016).

In The Last Jedi, the narrative focuses on Rey and her journey to become a Jedi and a member of the resistance against the First Order. Rey's story is not only functioning within the traditional male hero quest structure, but also directly mirrors Luke's narrative journey in the middle chapter of the original trilogy (episodes IV-XI). This is not to say that a female character cannot function in a heroic role that has been traditionally male, but that one cannot expect the character to function well when she has been copied and pasted into a story that was made for a man and has centuries of historical baggage associated with it regarding traditional gender roles. In other words, it would be much easier to "flip the script" of Star Wars with Rey's character and make her a heroic female if the story were not rooted in the conception that there is a universal human monomyth that has existed for thousands of years and the hero of that story is male. Recently there have been Disney films that appear to break some traditional gender models, such as the animated film Frozen. However, upon closer reflection, many authors have ultimately concluded that the film does rely on the very gender stereotypes (such as the power-hungry female villain, or feminine compassion) that the film appears to be breaking (Azmi et al. 2016; Streiff and Dundes 2017).

Keeping this in mind, the narrative of the film does allow for the three primary female characters to have memorable moments, but this is often in lieu of real character development. The audience 
is given little information regarding Holdo, we spend little time with Leia, and most of Rey's arc is focused on her relationships with Luke Skywalker and Kylo Ren. While the women are clearly taking the lead in this film (as is apparent with the leadership roles that both Holdo and Leia inhabit and Rey's ongoing journey to embody the light or "good" side of the Force) the male characters still enjoy the most development and richest scenes. Luke and Kylo are both allowed to display more emotion as they develop throughout the film, whereas the women are more even-keeled. Kylo oscillates between intense anger, a desire to connect with other characters, and stoicism. Luke is seen progressing from deep resignation, frustration, anger, to peace. Contrast this with Leia and Holdo who are both shown consistently as stoic in the face of surmounting odds, without much added emotional depth. Rey is allowed a bit more complexity, but even her emotional expression is fairly limited to stone-faced tears. In the official trailer for The Last Jedi, Rey is repeatedly shown pleading to both Luke and Kylo to either teach her or to "show me my place in all this," implying that she is more dependent on the male characters in the story than she actually is. This highlights the way in which the female characters are being positioned as leaders and important figures in the story, but are still subordinated to male wisdom, emotions, and experience regardless.

Alternatively, these three characters can be interpreted through a more positive and progressive lens. At the end of the second act, Holdo sacrifices herself by destroying the lead ship of the First Order, giving the surviving members of the Resistance the ability to flee to safety. Rey refuses Kylo's offer to rule alongside him and appears resolute in her quest to ride the galaxy of the evil of the First Order. Leia acts as a guardian of wisdom, passing down her knowledge to the next generation of leaders, whereas Luke refuses to do so for most of the narrative. Although there is no doubt that these characters present many good qualities and their narratives contain progressive elements, it is important to also acknowledge the classic sexist tropes that exist in this film that serve the interests of the gendered commodity market and the capitalist economy by which it is dictated. Can films made within this economic system truly be feminist or exhibit feminist themes? This is a question that will be returned to later in this article.

Kennedy vs. the Fans. It is important to note that, while the Disney Star Wars films have more recognizable and significant female characters, behind the scenes, the Star Wars franchise is overwhelmingly male. When The Last Jedi was released in December of 2017, and in the proceeding months, there was a great deal of vitriolic discourse amongst the fan community regarding the quality of the film. Many fans have chosen to blame Lucasfilm president Kathleen Kennedy (who took over when George Lucas sold the company to Disney) for whatever they do not like about the films or for any perceived failures that may occur. In the wake of disappointing box office returns for Solo: A Star Wars Story, "The Daily Caller" writer Jordan Whitley penned an op-ed blaming Kennedy for injecting feminism into the new Star Wars films, ignoring the core male customer base, openly mocking them, and showing preferential treatment to the female fans of the franchise (Whitley 2018). Notably, Kennedy is currently the only visible woman involved in the creation of the Star Wars films. Kennedy also has not been shy about making statements that have upset the core male fan base. She has explicitly stated that she does not owe anything to the male fans of Star Wars (Lucasfilm President Kathleen Kennedy Says She Doesn't Need to Cater to Male Star Wars Fans 2016), and she has proposed an industry commission to make Hollywood a safer place for women in the wake of the Weinstein scandal (Kathleen Kennedy Proposes Industry Commission and 'Zero Tolerance' in Wake of Weinstein Claims 2017). Kennedy's statements and actions as president, in conjunction with the increased presence of female characters in Star Wars films, has only increased the level of vitriol that many fans feel in a context that is already rife with racism and misogyny (Katz 2018).

While the narrative that, under the leadership of Kennedy, Lucasfilm gives preferential treatment to female audiences at the expense of the male fan base is popular, it is easy to see that the primary goal of Lucasfilm (and Disney) is to reach the largest possible audience. The official trailer for The Last Jedi was released during a Monday Night Football segment (notably, ESPN and ABC who broadcast Monday Night Football are both owned by Disney) (Thilk 2017). The cut of this trailer is also of note 
because it overemphasizes Kylo Ren's narrative in comparison to its significance in the film. Holdo is also absent from this preview of the film, and Leia does not speak. Thus, while the trailer is not representative of the actual narrative of the film, it is clear that Lucasfilm is trying to appeal to a male audience (although the Monday Night Football audience is most likely not the same audience as its most vocal fan base) by downplaying the significant female characters in the film within the trailer.

These small examples are an illustration of how Disney treats the female characters in the Star Wars franchise. While it is eager to incorporate women into the narrative so that they can access new markets, they are not interested in telling women's unique stories. The narratives of Rey, Holdo, and Leia, while promising at first glance, reveal that Disney is using the narrative language of feminism and women's movements in lieu of crafting female characters that are more than simply female versions of male character archetypes. This should not be framed as a successful feminist narrative. In order for a narrative or a character to be successfully feminist, that character or story should be conceived in such a way that her gender is a part of who she is, not simply a consequence of a marketing strategy constructed to broaden the audience of a film in the interest of selling merchandise. The works of author Angela Carter are an excellent example of how characters that are drawn from a traditional mythos can be reconceived with a feminist perspective (see The Bloody Chamber (Carter 1979) as an example). Thus, while the incorporation of major female characters seems to be positive, ultimately it amounts to little more than tokenism done in the interest of serving marketplace interests.

\subsection{Beauty and the Beast for a New Audience}

In an article in "The Huffington Post," Disney's latest rendition of Beauty and the Beast is praised as a film that "goes to great lengths to demonstrate Belle's agency in every part of the story," further appreciating the way Disney produced (retold) a movie providing more voice and agency to the female character (Gray 2017). Similar articles about the movie circulated during its release, creating a popular discourse that celebrated Beauty and the Beast as a feminist retelling of the fairy tale. However, a deeper analysis reveals that the movie perpetuates many tropes that reinforce the prevalent position of men and women in society.

To understand the origin of Beauty and the Beast as a contemporary fairy tale, it is important to look at the original story and its evolution thereon. The original story was written by Marie De Beaumont in the 18th century (Jeffords 1995, p. 165). In the original, a daughter of a merchant is held captive by a beast after she is asked to take the place of her father, who has stolen a rose from the Beast's garden. However, the daughter is pleasantly surprised that all her wishes are fulfilled in the magical castle. Slowly she begins to appreciate the Beast's intelligence and generosity, although she rejects his proposals for marriage. When the daughter realizes her father is ill, the Beast lets her go under the condition that she returns on her own within a specified time. The daughter fails to return to the castle, but realizes through a dream that the Beast is dying. She returns to the castle and expresses her love to the Beast, and, as a result, transforms the Beast into a handsome prince. The prince tells her about the curse he was under and with his power and wealth restored, marries the daughter, and they live happily ever after (Cummins 1995; Jeffords 1995).

This story was retold by Disney in 1991 in its animated version of The Beauty and the Beast, with some significant modifications to the story and the characters. Disney tried to bring the fairy tale to the big screen on two different occasions during the 1930s and 1950s, before it finally made it in 1991. In the past two attempts, the writers of Disney had found it hard to adapt the story to the big screen film format ('Beauty and the Beast 2017). Over five decades after the first Disney fairy tale film Snow White and Seven Dwarfs, The Beauty and the Beast, directed by Gary Toursdale and Kirk Wise, took over three and a half years to create (Ames 1991). The creators were able to overcome the constraints writers faced in the previous two attempts, by converting the long dinner conversations between the Beast and Belle in the original tale, into musical performances, along with the reimagination and introduction of various supporting characters (Ames 1991). The first draft, written by screenwriter Linda Woolverton, was not a musical, and did not have any of the talking household objects. However, 
everything changed with the release of The Little Mermaid. Disney had experienced a slump and needed something unique to recover. This pushed the producers to include music and the talking objects (Thomas and Hoad 2017). The writers were also aware of the criticism Disney had received for The Little Mermaid, for being sexist. This lead Woolverton to create Belle to be a strong, independent character. The movie was presented as a work-in-progress at the New York Film Festival in September 1991, with more than 35 percent of its animation still in black and white, yet it received a standing ovation for more than 10 minutes. The film was popular even before its official release (Ames 1991).

The Disney version has now become the canonical and definitive version of the fairy tale (Cummins 1995). This version privileges the romance plot, resulting in the sidelining of feminist elements of the original story (ibid). This change to favor the romance plot, emphasizes the relationship between Belle and the Beast, wherein Belle is objectified not just as the Beast's desire, but also an object that relieves the Beast of the curse. This objectification is revealed when Belle first enters the Beast's castle and the Beast's servants (cursed to take the form of household objects) comment that she is the girl who can undo the curse and that she is beautiful. Belle becomes the necessary object in the heterosexual relationship needed by the Beast. Her beauty supersedes her interests in books, as even her interests are used as a bait to woo her (Bryant 1989). Furthermore, Lieberman (1986) argues that fairy tales that end with marriage convey the message that marriage is the most important part of a woman's life. She points out that an ending with marriage automatically focuses the action of the film on courtship. This phase of courtship provides the woman with agency, but it all ends with the marriage. On the other hand, Rowe (1986) points out that marriages act as bridges between the realm of fantasy and reality, and thus construct the expectations of women viewers. The "Long, long ago in a place far, far away" leads the viewer into the world of fantasy; the marriage and courtship rituals connect them back to reality. Disney's retelling of the fairy tale, whether the 1991 animation or the more recent live-action rendition, emphasize the romantic relationship between Belle and the Beast, and conclude with them together. Both focus on the courtship period between Belle and the Beast, with the curing of the curse, and subsequently their marriage being the resolution. The resolution in both these retellings by Disney connect viewers back to reality; a reality that reinforces the prevalent hegemonic views of men and women, providing only a mask of agency to the female protagonist. What is interesting is that, when the animated movie was released in 1991, critics and reviewers appreciated the character of Belle as different compared to other Disney princesses, as she broke the prevalent sexist tropes and was a strong, independent female character (Cummins 1995). The same appreciation and celebration is seen in 2017, 26 years after the release of the animated movie.

The story in 2017 remained the same as Disney's 1991 animated rendition of The Beauty and the Beast. Belle, a bibliophile woman from a small French village is taken captive by a beast. The Beast (who is a prince) and other household items of the castle who are alive (and live as the prince's servants) are under a spell that can only be broken if the beast can make someone fall in love with him, which will bring them all back to their human form. The Beast falls in love with Belle, but lets her go when it becomes clear that her father is in danger. A soldier named Gaston wants to marry Belle, so he rallies the village to kill the Beast. Gaston is successful in mortally wounding the Beast, but Belle returns and confesses her love for the Beast, immediately breaking the spell and bringing the prince back to life (Barnes 2017). This plot, which was loosely adopted from the 18th century fairytale by Marie de Beaumontt (Jeffords 1995), remain intact with both renditions by Disney. However, certain significant changes in the film storylines shift the narrative voice from that of Belle to the Beast, a clear shift in favor of the male character.

Focus on the Beast. Disney's version also shifts the focus of the story from Belle to the Beast. Unlike the original story, where the readers come to know about the curse only at the end of the story, once the curse has been lifted, in the Disney versions (both the 1991 and 2017 versions) the viewers are introduced to the story with the prince being cursed by an enchantress, and thereby making it the story of the Beast (Jeffords 1995, p. 166). Instead of the curse appearing as the resolution part of narrative, in the Disney movies, it sets up the narrative. This reordering of the original narrative shifts 
the focus from Belle to the Beast. Cummins summarizes the story as "Beast gets girl, Beast loses girl, Beast gets girl back" (Cummins 1995, p. 23). The 2017 remake follows the same narrative and plot, making the movie the Beast's story. This also shifts the focus from Belle, to the victimization of the Beast, as viewers see that the Beast is also a prisoner in the castle like Belle, a trope that is absent in the original story in which the Beast controls all the magic in the castle (Jeffords 1995, p. 168). The focus of the story becomes how the Beast evolved to become better, and in that evolution, Belle is just an object. This makes the Beast the protagonist of the story, while Belle becomes a plot device needed for romance and as a solution to the Beast's problems, revealing the influence of the oedipal myth in Western narratives, in which the woman's story is nothing but the man's story, a narrative in which if the woman is successful, the man will get her/marry her (Bryant 1989).

Belle: Reading Woman to Inventor. Disney also brought in a lot of changes to the character of Belle. Belle has always been heralded by Disney as someone unlike other Disney princesses due to her interest in reading and adventure (Cummins 1995; Jeffords 1995, p. 167). "We spent a lot of time on Belle, trying to make her as modern as possible. She knows how to ride a horse, she knows how to shoot, she knows how to invent something, she knows how to fight, she knows how to read and teach. We wanted to give her modern qualities that are aspirational to young girls today. Everybody, including Emma, made a contribution to that" states the producer of the movie, Todd Lieberman (Rifkin 2017). According to director Bill Condon, the remake of the 1991 classic was needed to reinvent the protagonist Belle as a " $21^{\text {st }}$-century heroine" and present the story in a new format that was photoreal and live action in format. The major changes to the character of Belle was that she was an inventor, and apart from that, Disney added details of Belle's childhood and what happened to her mother (Holmes 2017). The movie illustrates that Belle wants to know about her childhood, but her father repeatedly avoids telling her. The Beast uses magic to reveal all the details of her childhood and provides closure to her questions. Here, the male characters adopt tropes such as a protective father, or benevolent beast, while the agency of Belle, her constant attempts to discover her history and her inquisitiveness, are overshadowed by the actions of the male characters. They protect Belle, they enable Belle to discover her past, while her own agency remains in the shadows.

Although Disney celebrates her as a princess who reads books, in the 1991 version, it is not clear what she reads about. In comparison, in the original tale by Beaumont, the author makes it clear that Beauty (and her readers subsequently) reads books about history, politics, philosophy, and religion. The 2017 version of the story shows Belle reading romantic tales about prince charming, her favorite Shakespearean drama being Romeo and Juliet, and she appreciates the Beast for reading a romantic novel. Here, Disney, as stated earlier, is not only emphasizing the romantic plot in the story as whole, but also emphasizing it in the interests of Belle, the kind of books she reads, and consequently her view of the world: her adventures will lead her to prince charming. This worldview of Belle (and ultimately the viewers) is reinforced in the song that she sings about a character meeting prince charming. Originally, Beaumont, writing in the context of 18th-century France, wanted to bring out a heroine who was a reading woman, who was not in pursuit of frivolous pleasures but in pursuit of knowledge, shown through the emphasis she put on the Beauty's love for music and specific kinds of books (Cummins 1995). In the 1991 and 2017 Disney versions, although reading is emphasized visually and in the narrative, it does not emerge as a significant trait except for in the beginning and a few scenes in the castle. Instead, Belle's ability to nurture takes over, be it the nurturing of the Beast or of her father.

The 2017 version of Beauty and the Beast was heralded as feminist because Belle was shown as an inventor. The movie portrays Belle working with her father in his workshop, displaying her knowledge in technology, by providing the tools her father needs even before her father realizes he needs them. Apart from this, Belle is also show working on an invention, testing a prototype, and the invention is finally revealed to the audiences to be a washing machine run by the power of a mule. While her invention is at work, Belle sits next to it reading a book, and then teaches a little girl how to read. The imagery of women and machines has transformed drastically in the last century. The images of 
women working in factories during the world wars, to Rosie the Riveter, influenced a change in how people perceived women and machines (Wosk 2001). However, after the Second World War, the agenda was for women to return to domestic life, and images of women with modern home appliances started to fill the postwar period of increased production. Refrigerators, washing machines, and stoves, which were technologically advanced and handled by women, created an image of technically adept women making use of their wartime knowledge of technology for domestic chores (Wosk 2001). This turn returned the woman back to domestic chores from the factory floor. The image of Belle inventing a machine to help in her household chores, putting it to use and nurturing a child, furthers this postwar image of the woman, who can do her daily chores while she nurtures her children thanks to technology. The tech innovator Belle of 2017 might be an inventor, but is limited to household chores similar to how women were expected to return to domestic chores after the war (Wosk 2001). The transformation of Belle from a reading woman in the original tale, to an adventure loving and educated one in 1991, to a tech innovator in 2017 , is a significant one, but confines her within the gendered roles prevalent in society, especially women holding the responsibility of housework.

The reversal of roles in celebrated in this movie; it does not challenge the dominant patriarchy, but instead remains within the comfort of reinstating what it means to be masculine and feminine in a patriarchal society. To understand this reinstatement, one needs to look at the changes in society during the 80s. Although, there was a radical change in the kind of work taken up by women in the 80s, there was no change in the gender perspectives associated with domestic labor: in addition to any new responsibility women took up, they still had to undertake domestic labor (Lupri 1983). This shift in roles of gender was reflected in Hollywood too, with movies such as Kindergarten Cop and Three Men and a Baby, which reiterated the need for women to be in domestic spaces by representing the awkwardness of men in female/domestic roles (Traube 1992). The concept of the "cult of the home" by Benston (1971) argues that the domestic role of women and their presence in that particular labor is essential to, but inferior to, the wage-earning labor of men, and acts as a constant reserve of surplus labor. Movies portraying such gender role reversals consequently represent women being required to give-up their new responsibilities and return to the domestic realm to sustain the dominant hegemonic gender roles (Carrier 2015). Gender role reversals also provide mixed messages, in which the female character always displays domesticated femininity, during her role as a strong, independent character (Ross and Carolyn 2006). In most cases, movies with strong, independent female characters, display opposing traits such as, "acts of rebellion combined with gestures of respect, beauty and brains, power and submission, sexuality and timidity"- so all viewers can relate to and enjoy something (Dutt 2014, p. 9). This is explicitly seen in Beauty and the Beast, in which Belle rebels against Beast and enters the restricted west-wing, portraying rebellion and power, immediately juxtaposed by timidity (fear of retribution, the act of running away, fear of the wolves), and the heroic rescue by the Beast. Following the rescue, Belle automatically assumes a submissive role to a domestic caretaker by helping and treating the injured Beast and thanking the Beast for saving her. The display of opposing traits is also portrayed when Belle is made the object of beauty in Gaston's eyes (consequently in the viewer's eyes as well), but is immediately shown as the "brainy" kind of woman with her reading of books and inventing of gadgets. However, this image of "inventor, brainy Belle" is short-lived, when she invents a washing machine, bringing her back to the submissive realm of domesticity.

Beauty and the Beast in the Age of Watson and Weinstein. Although the latest rendition of Beauty and the Beast has aspects that can be read as feminist, a deeper analysis reveals that painting the movie as feminist is problematic. In an age when Hollywood is rocked by the sexual assault scandals of Harvey Weinstein, Susan Jeffords analysis of the 1991 The Beauty and the Beast as a "tale helps to forward the image of unloved and unhappy white men who need kindness and affection, rather than criticism and reform, in order to become their 'true selves' again" (1995, p. 165) rings relevant to Beauty and the Beast. The rendition of the same tale with a few changes, most importantly having the ambassador of United Nations' HeForShe campaign, Emma Watson, play Belle, and her becoming a plot device to transform men (the Beast), cannot be a feminist retelling. The story still focuses on 
the Beast, the construction of masculinity/femininity is still hegemonic, the Beast's wrongdoing is not his fault but he needs a woman to make himself into a complete man, and in the end, the desire of Belle for adventure and travels end with her being with the prince. As a cherry on the cake of constructing hegemonic masculinity, Belle even asks the prince if he can grow a beard in the final shot of the 2017 movie.

The movie Beauty and the Beast might not be a feminist retelling, but when one looks at the content in relation to the political economy, the rationale for the production of the movie at this particular moment becomes clear. Disney revamped their plans for movie production, focusing on sequels and remakes, of which Beauty and a Beast was one.

Disney CEO Bob Iger informed his shareholders about the enthusiasm behind Beauty and the Beast by pointing out the number of views the movie's trailer had on YouTube. The movie had to bring in money as it had to cover Disney's massive US\$300 million budget for production and global marketing (Rainey 2017). The movie was produced by David Hoberman and Todd Lieberman, both veteran movie producers (Rainey 2017). The producers had approached Disney in 2008 to produce a remake of The Beauty and the Beast from the perspective of the Beast and create a darker version of the original. Disney was skeptical about producing a dark version of one of the favorite movies of its renaissance period. With the tremendous success of Frozen in 2013, Disney knew the advantage of presenting strong female protagonists, and therefore asked the producers to remake Beauty and the Beast accordingly (Rainey 2017; Rysdall and Bodnar 2017). Disney and the producers of the movie state that they are in the business of providing upbeat happy endings, and business in the past few years has been good (Hayes 2017).

Iger noted in his annual report that Disney was having great success in re-imagining all the classics in live action format, beginning with Maleficent, Cinderella, and The Jungle Book. He said that reimagining Beauty and the Beast for the new generation was part of the plan to release The Lion King, Aladdin, Dumbo, and Mulan in the next few years in live action format (Iger 2017). Commenting on the same, Christine McCarthy, senior executive director and CFO, Walt Disney Company, commented that the strategy was to have movies that would cross a certain threshold in the box office. Disney's strategy is to create brands and franchises that support the studio financially (tent poles). Based on this strategy, she noted, "In general you will see one to two Star Wars, two to three animated movies and they could be both from Pixar and Feature animation, two to four Marvel movies, we do have four next year that are being released. And the balance will be Disney live action" (McCarthy 2017, p. 9). Furthermore, she noted that the strategy for Disney live action was to reimagine Disney intellectual properties in live action format, which began with Maleficent, and each of these reimaginations, including Beauty and the Beast, has averaged US\$650 million at the box office, which shows the success of the strategy (McCarthy 2017). Commenting on the reboot culture of Disney, Desta (2017) pointed out, “Disney's rebooting strategy is also working to reel in new viewers (who will hopefully then take their children to the reboot of the reboot in 2037, and so on and so forth, forever and ever, amen)."

At a time when a majority of audiences of Hollywood movies are women, $60 \%$ of the audience for Beauty and the Beast were women, while $72 \%$ were women during the opening weekend in North America (Desta 2017). Their marketing was also aimed at millennial mothers. Disney marketed Beauty and the Beast on The Bachelor (season 21), with Luke Evans and Josh Gad hosting the show on 30 January, which included a release of one of the trailers (Freeman 2017). The Bachelor is a telecast on $\mathrm{ABC}$, which is also owned by Disney. Advertisers are interested in The Bachelor, as almost $75 \%$ of its audience are women. Moreover, its biggest audience is the 18-49 demographic and rates high in households with an average annual income of US\$100,000 or more (Berg 2016). Disney even bought ads in the newly released Google Home assistant, in which Google Home provided the weather and news and ended it with, "By the way, Beauty and the Beast opens in theaters today. In this version, Belle is the inventor. Sounds more like it to me" as reported by several users (Roberts 2017). Disney's cross promotions and tie ins were aimed at products and services that would suit and attract millennial mothers (Palmeri and Townsend 2017). 
It is evident from these examples that the motive driving Disney to release Beauty and the Beast was not a feminist one, but profit and market logic, targeted at specific audiences. The profit arising from sales is supplemented by the fact that Beauty and the Beast is a Disney property, thereby allowing the company to extract more revenue exploiting its ownership of the rights, a phenomenon which, according to the CEO, will continue for the next few years.

\section{Discussion}

The reality of the gendered commodity market and the ways in which it functions within the contemporary film industry brings up many complex theoretical issues from both a feminist political economy perspective and a socialist feminist theory perspective. Questions about the role of neoliberalism within the marketplace, the politics of postfeminism, commodity feminism, and the possibility of creating feminist media texts within this economic and cultural space all rise to the surface when addressing these films. The rise of neoliberal politics appears to be at the root of these inquiries.

In David Harvey's A Brief History of Neoliberalism, he defines the term as, "a theory of political economic practices that propose that human well-being can best be advanced by liberating individual entrepreneurial freedoms and skills within an institutional framework characterized by strong private property rights, free markets, and free trade" (Harvey 2005, p. 2). While Meehan does not bring up this particular ideology in her work on the gendered commodity market (2002), it seems as though neoliberalism has particular relevance in the context of these two media texts and the cultural landscape of this decade in general. As Harvey states: "It [neoliberalism] has pervasive effects on ways of thought to the point where it has become incorporated into the common-sense way many of us interpret, live in, and understand the world" (Harvey 2005, p. 3). A focus on individual determination and rising above circumstance in the service of rejecting critiques of systemic oppression characterizes a neoliberal social position.

This social position fuels the postfeminist perspective of female "empowerment." Rosalind Gill calls this a "sensibility" as opposed to a concretely definable philosophy and characterizes it as: "the notion that femininity is a bodily property; the shift from objectification to subjectification; the emphasis upon self-surveillance; monitoring and discipline; a focus upon individualism; choice and empowerment; the dominance of a makeover paradigm; a resurgence in ideas of natural sexual difference; a marked sexualization of culture; and an emphasis upon consumerism and the commodification of difference" (Gill 2007, p. 149). This sensibility clearly builds off of the rhetoric of neoliberalism and works to benefit the goal of the gendered commodity market: commodifying difference.

This leads to a discussion of what has been termed "commodity feminism." Goldman, Heath, and Smith describe this phenomenon as a restructuring of feminist ideology to work within a western patriarchal society (Goldman et al. 1991). They say, "When framed by ideologies of possessive individualism and free choice, feminism in its 'new' commodity form forgets its origins in a critique of unequal social, economic and political relations" (Goldman et al. 1991, p. 336). In other words, feminism (specifically the postfeminist sensibility) becomes focused on "girl power" and a women's ability to "vote with her wallet" as opposed to seeking ways to deconstruct harmful social structures. Commodity feminism allows women to identify with their femininity and their "empowerment" through consumerism; it allows them to adopt a set of heavily-sterilized feminist "attitudes which they can then wear" (Goldman et al. 1991, p. 336).

At the narrative level, The Last Jedi appears to offer a rather bland message of collective action in the face of a fascist threat (a threat that is all too real in the "real world"). Rey, Holdo, and Leia act as female leaders of that collective action. However, there is no examination of the social structures that may have led to the resurgence of fascism in the galaxy after its defeat by the rebellion (e.g., ineffective chains of individualistic command and respect for military authority, a lack of a concerted effort to educate "regular" people in the use of the Force and democratize traditional Jedi knowledge, etc.). Instead, the film offers the type of role-reversal that is characteristic of liberal feminist politics which seeks to preserve traditional social structures, but with more women and other oppressed individuals 
gaining power. Whereas, under a socialist feminist agenda, oppressive social structures would be dismantled in the interest of creating new structures that would create a more equitable society for all. This alliance with the sensibility of liberal feminism allows for the narrative to be easily crafted into a marketing campaign that targets both the audience of males 18-34 as well as the gendered commodity market of women, who have been exposed to postfeminist rhetoric and bombarded with an ethics of commodity feminist consumerism on a daily basis. A similar narrative can be found in Beauty and the Beast, in which the radical transformation which Belle brings about in the Beast (leading to lifting of the curse), makes the Beast as an individual a "better person." Once the curse is lifted, the audience witnesses a transformation of the Beast, the castle, the talking objects and the castle garden. However, the position of Beast/Prince as the owner of the castle, and the transformed talking objects as the "loyal" servants, remain unchanged. Belle also takes up a position parallel to the Beast/Prince, with the servants subordinate to her. This reflects, as stated before, the characteristic of liberal feminist politics.

Apart from the neoliberal feminist narratives in these films, the design elements of both characterize what Mirrlees (2014) terms globally popular entertainment media or, "Blockbuster Event films" in particular. These films are designed in a way to reach and relate to audiences across the whole world, suit their preferences and ensure profits for corporations (Mirrlees 2013). Design characteristics of such movies include global stars, pre-sold properties, genre hybridity, classical narrative structures, universal themes and visual spectacles (Mirrlees 2013). The Last Jedi and Beauty and the Beast are Blockbuster Event Films.

The casting of stars in a Hollywood movie are important because the presence of this "image-commodity" attracts some viewers to consume the movie (Mirrlees 2013). While Beauty and Beast cast the globally popular Emma Watson, The Last Jedi roped in an international cast including the British actors Daisy Ridley and John Boyega, as well as Kelly-Marie Tran, the Vietnamese-American (Lopez 2017). Both movies are also pre-sold properties which have an existing audience who has either seen previous movies, or read comic books and fairy tales. While Beauty and the Beast can be classified within the fantasy genre of film, The Last Jedi contains elements of both fantasy and science fiction. A characteristic of Blockbuster event films is that they do not represent reality, but instead create a completely new "fantastical reality" (Mirrlees 2013, p. 187). Both movies perform this act of constructing a new fantastical realm, be it the French village and the castle in Beauty and the Beast, or the continuation of the Star Wars galaxy in The Last Jedi. This construction of new realms allows Disney to target a wider audience, create merchandise, and allow for the creation of 'esoteric knowledge,' resulting in fan groups and communities (Mirrlees 2013). As observed in the analysis of the two movies, although the films create a whole new reality, they still conform to hegemonic norms of patriarchy. This conformation is also observed in the conservative narrative form of the two movies. The absence of complex experimental camera shots, radical use of lighting, and unrelatable scenarios are avoided in blockbuster event films (Mirrlees 2013). The discontinuation of Beauty and the Beast in 2008, which was supposed to have a darker version points to this phenomenon; as an experimental narrative such as that would not be relatable to a large audience.

Finally, both movies offer a visual spectacle displaying "spectacular imagery, often utilizing the latest in special effects and other technologies" (King 2002, p. 178). The use of live-animation action in Beauty and the Beast and complex CGI and visual effects in The Last Jedi, provide audiences a visually rich experience, devoid of heavy dialogues, with constant presentations of, what Jenkins (2006) calls, "Wow Climax" (e.g., the ballroom dance in Beauty and the Beast; the sacrifice of vice-admiral Holdo in The Last Jedi).

Furthermore, both films exhibit the economic characteristics of a blockbuster event film: big budget [The Last Jedi had a net production cost of \$200 million (D'Allesandro 2018b)]; big marketing [Disney spent $\$ 175$ million on worldwide ads of Beauty and the Beast (D'Allesandro 2018a). For The Last Jedi, Disney spent $\$ 185$ million (D'Allesandro 2018b)]; big release [The Last Jedi had a global box office collection of \$1332 million (D'Allesandro 2018b). Beauty and the Beast had \$1263 million (D'Allesandro 2018a)]; big synergy and global audience (Mirrlees 2014). The categorization of both these films as blockbuster event films points to the fact that for Disney, these two are commodities designed to ensure 
profits, through creating a specific design of films which can be consumed by the masses, but also to capitalize on commodity feminism.

Disney, at the end of the day, is a corporation and aims to create profits for its shareholders. Disney also owns the copyrights for both Beauty and the Beast and The Last Jedi, and therefore capitalizes on revenue from these copyrights. It owns these two commodities perceived to be pro-feminist movies. Bob Iger has also presented Disney's plan for the next few years as one involving re-imagining Disney properties, reducing the possibility of Disney producing films with new narratives and original female characters created from scratch. Moreover, Disney as a corporate entity has not been a champion of achieving gender rights within the company. The top management team and the Board of Directors consists of 23 executives, of which only seven are women (About 2018). Apart from the underrepresentation of female characters in its movies (Robehmed 2016), Disney has also reported that in its wing located in England, a male employee is paid 22\% more than a female employees, while there exists a $41.9 \%$ gap in bonuses paid (Clarke 2018). No information about wage or salary gaps were found for Disney's United States wing. Alan Horn, Chairman of Walt Disney Studio, noted, "Audiences have proven that there's an appetite and a market for dynamic female leads and female-driven stories, and as an industry, we have a responsibility to create those roles for women and compensate them accordingly" (Berg 2015). What this quote conveys is the motive and rationale behind Disney creating "feminist" films is not concern for women in society, but the market which they want to capture, to ensure constant profits.

Thus, this raises the question: can a feminist film be made? The answer, predictably, is complicated. Because of the inherently oppressive nature of capitalism, it is hard to envision a film that can truly be feminist from both a critical theoretical standpoint and a political economic standpoint. Capitalist systems will inevitably encourage the exploitation of workers and, even more so, women in the film industry (as the Weinstein scandal has revealed to the masses). On this premise alone, a truly feminist film cannot be made within a capitalist system. However, this is not to suggest that some films cannot contain feminist themes or achieve greater degrees of feminism than others. It is certainly not ideal to measure films or compare them according to their degrees of feminism, but under the current global economic system, capitalism is the status quo and it is very hard to work outside of that system. Even "independent" cinema as is traditionally conceived is no longer truly independent, as indie film companies are consistently purchased by media conglomerates. Hence, for a film to function more actively as a (socialist) feminist text within the contemporary capitalist structure, it might exhibit some of the following characteristics: including characters from oppressed populations who are neither defined by their oppressed status nor are simply code-switched with originally privileged characters; ensuring that individuals from oppressed communities are involved in all levels of the production of the film and are fairly compensated; avoiding marketing strategies that target commodity audiences; avoid neoliberal and postfeminist rhetoric and sensibilities that overemphasize individual ability to overcome structural marginalization; ensuring that any feminist themes in either the narrative of the film or extratextual materials do not embody an ethics of commodity feminism, and instead one of active, participatory feminism.

\section{Conclusions}

In 2017 alone, Disney has shown that, while it is happy to present itself as a company that holds the interests of girls and women at heart, it is truly only concerned with profiting from them. The narratives of both Beauty and the Beast and The Last Jedi exemplify that there is not a willingness within the company to search for new narratives outside of what it has tried and succeeded with before. Not only are both of these films either reboots or sequels, but they both reimagine traditional characters in a way that the audience is supposed to read as "feminist" when they are not truly more progressive than originally conceived.

Disney saw that there was a growing social movement fueled by grassroots activism and internet connectivity that brought women and other marginalized groups together more than ever, encouraging 
each other to speak up on behalf of each other's rights. This presented an economic opportunity to sell much of its repurposed film library as "feminist" retellings of classic stories and produce merchandise that focused on "girl-power" and catered to women specifically. However, this is no substitute for telling the story of women in the real world, in the fantasy world, or in the world far, far away. More must be demanded of our media makers who create narratives and they should be held to a higher standard when they imply that they are telling these narratives for the greater good of the world.

Author Contributions: K.K. conceived of the analysis. He wrote the political economy section of the literature review, as well as the analysis of Beauty and the Beast. A.R. contributed material regarding feminist political economy and feminist film theory and criticism to the literature review. She wrote the analysis of Star Wars: The Last Jedi. Each author revised sections of the paper.

Funding: This research received no external funding.

Acknowledgments: The authors wish to thank Jennifer Proffitt and the anonymous reviewers for their many helpful suggestions during the revision process.

Conflicts of Interest: The authors declare no conflict of interest.

\section{References}

About. 2018. The Walt Disney Company. Available online: https:/ /www.thewaltdisneycompany.com/about/ (accessed on 18 October 2018).

Ames, Katrine. 1991. Just the Way Walt Made Em. Newsweek, November 17. Available online: https://www. newsweek.com/just-way-walt-made-em-202018 (accessed on 10 May 2018).

Atkinson, Joshua, and Bernadette Calafell. 2009. Darth Vader made me do it! Anakin Skywalker's avoidance of responsibility and the gray areas of hegemonic masculinity in the Star Wars Universe. Communication, Culture $\mathcal{E}$ Critique 2: 1-20. [CrossRef]

Azmi, N.J., Radzuwan Ab Rashid, Mairas Abd. Rahman, and Safawati Basirah Zaid. 2016. Gender and speech in a Disney princess movie. International Journal of Applied Linguistics and English Literature 5: 235-39. [CrossRef]

Baker, Liana. 2013. GE to sell rest of NBC stake to Comcast for $\$ 16.7$ billion. Reuters, February 13. Available online: https:/ / www.reuters.com/article/us-ge-nbc-idUSBRE91B1IM20130212 (accessed on 10 May 2018).

Barnes, Brooks. 2017. 'Beauty and the Beast': Disney's \$300 Million Gamble. New York Times, March 8. Available online: https://www.nytimes.com/2017/03/08/movies/beauty-and-the-beast-disneys-300million-Gamble.html (accessed on 10 May 2018).

Barsanti, Sam. 2018. Some creep made an overtly sexist edit of The Last Jedi, and even they think it's awful. $A V$ Club, March 7. Available online: https:/ /www.avclub.com/some-creep-made-an-overtly-sexist-edit-of-thelast-jedi-1822104868 (accessed on 7 March 2018).

'Beauty and the Beast': Revisiting the Animated Classic. 2017. Biography, March 15. Available online: https: / / www.biography.com/news/beauty-and-the-beast-facts-animated-movie (accessed on 10 May 2018).

Benston, Margaret. 1971. The Political Economy of Women's Liberation. In Roles Women Play: Readings toward Women's Liberation. Edited by Michele Hoffnung. Belmont: Brooks/Cole Publishing Company.

Berg, Madeline. 2015. Everything You Need To Know About The Hollywood Pay Gap. Forbes, November 12. Available online: https:/ / www.forbes.com/sites/maddieberg/2015/11/12/everything-you-need-to-knowabout-the-hollywood-pay-gap/\#47b417955cf1movie (accessed on 18 October 2018).

Berg, Madeline. 2016. For ABC And 'The Bachelorette,' The Honeymoon Period Is Everlasting. Forbes, August 2. Available online: https:/ / www.forbes.com/sites/maddieberg/2016/08/02 / for-abc-and-the-bachelor-thehoneymoon-period-is-everlasting/\#52ff8f606ac8movie (accessed on 10 May 2018).

Bettig, Ronald, and Jeanne Hall. 2012. Big Media, Big Money: Cultural Texts and Political Economics. Boulder: Rowman \& Littlefield Publishers, Inc.

Box Office Mojo. 2017. Available online: http:/ /www.boxofficemojo.com/yearly/chart/?view2=worldwide\&yr= 2017\&p=.htm (accessed on 30 March 2018).

Bryant, Slyvia. 1989. Reconstructing Oedipus through Beauty and the Beast. Criticism: A Quarterly for Literature and Arts 31: 439-53.

Carrier, Micheal. 2015. Men and the Movies: Labor, Masculinity, and Shifting Gender Relations in Contemporary Hollywood Cinema. Ohio University. Available online: https:/ / etd.ohiolink.edu/!etd.send_file?accession= ohiou1430322393\&disposition=inlinemovie (accessed on 18 October 2018). 
Carter, Angela. 1979. The Bloody Chamber. New York: Penguin.

Clarke, Stewart. 2018. Disney Reports 22\% Pay Gap in Favor of Men in Britain, NBCU a Gap of 3.2\%. Variety, March 30. Available online: https:/ / variety.com/2018/biz/news/disney-nbc-gender-pay-gap-uktvall3media-1202740354/ (accessed on 18 October 2018).

Croteau, David, and William Hoynes. 2006. The Business of the Media: Corporate Media and the Public Interest. Thousand Oaks: Pine Forge Press.

Cummins, June. 1995. Romancing the Plot: The Real Beast of Disney's Beauty and the Beast. Children's Literature Association Quarterly 20: 22-28. [CrossRef]

D'Allesandro, Anthony. 2018a. No. 2 ‘Beauty and the Beast’ Box Office Profits-2017 Most Valuable Blockbuster Tournament. Deadline, March 27. Available online: https:/ / deadline.com/2018/03/beauty-and-the-beastbox-office-profits-1202351594/ (accessed on 18 October 2018).

D'Allesandro, Anthony. 2018b. No. 1 'Star Wars: The Last Jedi' Box Office Profits-2017 Most Valuable Blockbuster Tournament. Deadline, March 28. Available online: https:/ / deadline.com/2018/03/star-wars-the-last-jedibox-office-movie-profits-1202351603/ (accessed on 18 October 2018).

Davis, Scott. 2017. Disney as Master Marketer: A Tale as Old as Time. Forbes, March 22. Available online: https:/ /www.forbes.com/sites/scottdavis/2017/03/22/beautyandthebeast/\#18766e8a44cc (accessed on 18 October 2018).

Desta, Yohana. 2017. How Beauty and the Beast Became One of Disney's Most Profitable Gambles. Vanity Fair, March 23. Available online: https:/ /www.vanityfair.com/hollywood/2017/03/beauty-and-the-beastanimated-box-office (accessed on 10 May 2018).

Dutt, Reema. 2014. Behind the curtain: women's representations in contemporary Hollywood. LSE. Available online: http:/ /www.lse.ac.uk/media@lse/research/mediaWorkingPapers/MScDissertationSeries/2013/ msc/112-Dutt.pdf (accessed on 18 October 2018).

Florio, Angelica. 2017. Why Laura Dern's Holdo Is the Most Badass Character in the Last Jedi. Bustle, December 18. Available online: https: / www.bustle.com/p/laura-derns-holdo-in-the-last-jedi-defies-a-sexist-trope-tobecome-a-badass-hero-7611685 (accessed on 2 April 2018).

Freeman, Molly. 2017. Beauty and the Beast Stars to Host Episode of the Bachelor. ScreenRant, January 18. Available online: https:// screenrant.com/disney-beauty-beast-bachelor-luke-evans-josh-gad/ (accessed on 10 May 2018).

Gertrude, Bitter. 2018. Why so Many Men Hate the Last Jedi but can't Agree on Why. BitterGertude, April 2. Available online: https:/ / bittergertrude.com/2018/01/04/why-so-many-men-hate-the-last-jedi-but-cantagree-on-why/ (accessed on 2 April 2018).

Gill, Rosalind. 2007. Postfeminist media culture: Elements of a sensibility. European Journal of Cultural Studies 10: 147-66. [CrossRef]

Goldman, Robert, Deborah Heath, and Sharon L. Smith. 1991. Commodity Feminism. Critical Studies in Mass Communication 8: 333-51. [CrossRef]

Gomery, Douglas. 2004. The economics of Hollywood: Money and Media. In Media Economics: Theory and Practice. Edited by Alison Alexander, James Owers, Rod Carveth, Ann Hollifield and Albert Greco. Mahwa: LEA Publishers, pp. 193-206.

Gonzalez, Umberto. 2018. JJ Abrams Slams Star Wars Fans Who Didn't Like Last Jedi as 'Threatened' by Women. The Warp, February 16. Available online: https:/ / www.thewrap.com/jj-abrams-star-wars-fans-last-jedi/ (accessed on 2 April 2018).

Gray, Emma. 2017. How Disney Subtly Made 'Beauty and the Beast' More Feminist. HuffPost, March 21. Available online: https: / www.huffingtonpost.in/entry/how-disney-subtly-made-beauty-and-the-beastmore-feminist_us_58cfd97ce4b0ec9d29dd676f (accessed on 10 May 2018).

Hardy, Jonathan. 2014. Critical Political Economy of the Media: An Introduction. New York: Routledge.

Harvey, David. 2005. A Brief History of Neoliberalism. New York: Oxford University Press.

Hayes, Dade. 2017. Beauty and the Beast' Producers Build Business on Happy Endings. Forbes, March 17. Available online: https:/ / www.forbes.com/sites/dadehayes/2017/03/17/beauty-and-the-beast-producersbuild-business-on-happy-endings/\#45541fcb24f7 (accessed on 18 October 2018).

Holmes, Andy. 2017. Why Beauty and the Beast Needed to Be Remade, According to the Director. CinemaBlend, May 14. Available online: https://www.cinemablend.com/news/1625579/why-beauty-and-the-beastneeded-to-be-remade-according-to-the-director (accessed on 10 May 2018). 
Iger, Bob. 2017. Q2 FY17 Earnings Conference Call. [REPORT]. Available online: https://www. thewaltdisneycompany.com/wp-content/uploads/q2_fy17_earnings_transcript.pdf (accessed on 10 May 2019).

Jeffords, Susan. 1995. The Curse of Masculinity: Disney's Beauty and the Beast. In From Mouse to Mermaid the Politics of Film Gender and Culture. Edited by Elizabeth Bell, Lynda Haas and Laura Sells. Bloomignton: Indiana University Press, pp. 161-72.

Jenkins, Henry. 2006. The Wow Climax: Tracing the Emotional Impact of Popular Culture. New York: New York University Press.

Jensen, Jeff. 1999. 'Star Wars' Toys Create a Buying Frenzy. Entertainment Weekly, May 6. Available online: https://ew.com/article/1999/05/06/star-wars-toys-create-buying-frenzy/?fbclid= IwAR2V2bPxgZnm1YlcbSBLk8ADLqJ81M6xkrnRaI5eZezsNFh5cryPJeUhHdQ (accessed on 18 October 2018).

Jess-Cooke, Carolyn. 2009. Film Sequels: Theory and Practice from Hollywood to Bollywood. Edinburgh: Edinburgh University Press.

Johnson, Derek. 2014. May the Force be with Katie: Pink media franchising and the postfeminist politics of HerUniverse. Feminist Media Studies 14: 895-911. [CrossRef]

Kathleen Kennedy Proposes Industry Commission and 'Zero Tolerance' in Wake of Weinstein Claims. 2017. Hollywood Reporter, October 16. Available online: https:/ / www.hollywoodreporter.com/news/kathleenkennedy-demands-zero-tolerance-policies-wake-weinstein-allegations-1049421 (accessed on 31 May 2018).

Katz, Brandon. 2018. Racism, Misogyny \& Death Threats: How Star Wars Fans Turned to the Dark Side. Observer, May 16. Available online: http://observer.com/2018/05/star-wars-fandom-toxic-disney-lucasfilm/ (accessed on 31 May 2018).

King, Geoff. 2002. New Hollywood Cinema: An Introduction. New York: I.B. Tauris.

La Monica, Paul. 2017. Hasbro has 'Monopoly' with toy fans as Mattel struggles. CNN Business, June 22. Available online: https://money.cnn.com/2017/06/22/investing/hasbro-mattel-toys/index.html (accessed on 18 October 2018).

Lang, Brett. 2017. 'Beauty and the Beast': 5 Reasons the Disney Fantasy Scored at the Box Office. Variety, March 19. Available online: https:/ /variety.com/2017/film/box-office/beauty-and-the-beast-emma-watson-boxoffice-1202011723/ (accessed on 18 October 2018).

Larabee, Ann. 2016. Editorial: Star Wars and the girl hero. The Journal of Popular Culture 49: 7-9. [CrossRef]

Lieberman, Marcia. 1986. Someday my prince will come. In Don't bet on the Prince: Contemporary Feminist Fairy Tales in North America. Edited by Jack Zipes. New York: Methuen.

Lopez, Ricardo. 2017. Women and Non-White Characters Are Speaking More in Recent Star Wars Movies. Variety, December 8. Available online: https:/ / variety.com/2017/film/news/star-wars-diversity-dialogue-bechdeltest-rogue-one-1202633473/ (accessed on 18 October 2018).

Lucasfilm President Kathleen Kennedy Says She Doesn't Need to Cater to Male Star Wars Fans. 2016. Comicbook, November 29. Available online: https://comicbook.com/starwars/2016/11/29/lucasfilm-presidentkathleen-kennedy-says-she-doesnt-need-to-cat/ (accessed on 31 May 2018).

Lupri, Eugen. 1983. The Changing Positions of Women and Men in Comparative Perspective. In The Changing Position of Women in Family and Society. Edited by Eugen Lupri. Leiden: Brill.

McCarthy, Christine. 2017. 4th Annual MoffettNathanson Conference [Speech Transcript]. Available online: https:/ / www.thewaltdisneycompany.com/wp-content/uploads/cmm-moffnath-transcript-051717.pdf (accessed on 10 May 2018).

McChesney, Robert. 2008. Political Economy of Media: Enduring Issues, Emerging Dilemmas. New York: Monthly Review Press.

Meehan, Eileen. 2002. Gendering the Commodity Audience: Critical Media Research, Feminism, and Political Economy. In Media and Cultural Studies: Key Works. Oxford: Blackwell, pp. 311-21.

Meehan, Eileen. 2005. Why TV Is Not Our Fault: Television Programming, Viewers, and Who Is Really in Control. Boulder: Rowman and Littlefield Publishers, Inc.

Mendelson, Scott. 2017. Beauty And The Beast’ Passes \$1 Billion As Disney And Universal Rule The Box Office. Forbes, April 13. Available online: https:/ /www.forbes.com/sites/scottmendelson/2017/04/13/beautyand-the-beast-passes-1-billion-as-disney-and-universal-dominate-top-tier-box-office/\#1351344522f4 (accessed on 10 May 2018).

Miller, Toby, Nitin Govil, John McMurria, Richard Maxwell, and Ting Wang. 2005. Global Hollywood 2. London: British Film Institute. 
Mirrlees, Tanner. 2013. Global Entertainment Media. New York: Routledge.

Mirrlees, Tanner. 2014. xXx: Global imperial pop. American Communication Journal 16: 29-42.

Moore, James. 2017. Star Wars: The Last Jedi Has Been Killed off by PC Culture. No Really, People Actually Think That. Independent, December 21. Available online: http:/ / www.independent.co.uk/voices/star-wars-last-jedijohn-boyega-daisy-ridley-pc-culture-backlash-rotten-tomatoes-a8122146.html (accessed on 7 March 2018).

Mosco, Vincent. 2009. The Political Economy of Communication. Thousand Oaks: Sage.

Mulvey, Laura. 1975. Visual pleasure and narrative cinema. Screen 16: 6-18. [CrossRef]

Mythic Discovery: Revisiting the Meeting between George Lucas and Joseph Campbell. 2015. StarWars, October 22. Available online: https://www.starwars.com/news/mythic-discovery-within-the-inner-reaches-ofouter-space-joseph-campbell-meets-george-lucas-part-i (accessed on 21 April 2018).

Norris, Vincent. 1990. The political economy of communications: An exploration of fundamental concepts. In Circulation: Working Papers. State College: School of Communications, Pennsylvania State University.

Palmeri, Chirstopher, and Matthew Townsend. 2017. Beauty and the Beast's Biggest Target? Nostalgic Millennials. Bloomberg, March 16. Available online: https:/ /www.bloomberg.com/news/articles/2017-03-16/beautyand-the-beast-s-biggest-target-nostalgic-millennials (accessed on 10 May 2018).

Pendakur, Manjunath. 1990. Canadian Dreams and American Control: The Political Economy of the Canadian Film Industry. Detroit: Wayne State University Press.

Proffitt, Jennifer, Djung Yune Tchoi, and Matthew P. McAllister. 2007. Plugging back into The Matrix: The intertextual flow of corporate media commodities. Journal of Communication Inquiry 31: 239-54. [CrossRef]

Rai, Shirin M., and Georgina Waylen. 2013. Feminist Political Economy. In New Frontiers in Feminist Political Economy. Edited by Shirin Rai and Georgina Waylen. New York: Routledge, pp. 1-18.

Rainey, James. 2017. Meet the Producers Who Breathed New Life into 'Beauty and the Beast'. Variety, March 15. Available online: http://variety.com/2017/film/features/disney-live-action-beauty-and-the-beast1202007900 / (accessed on 10 May 2018).

Rifkin, Jesse. 2017. A Tale as Old as Time: 'Beauty and the Beast' Producers Todd Lieberman and David Hoberman on Disney's Latest Live-Action Fairy Tale. BoxOffice Pro, March 14. Available online: https: / / pro.boxoffice.com/tale-old-time-beauty-beast-producers-todd-lieberman-david-hobermandisneys-latest-live-action-fairy-tale/ (accessed on 10 May 2018).

Riordan, Ellen. 2002. Intersections and New Directions: On Feminism and Political Economy. In Sex and Money: Feminism and Political Economy in the Media. Edited by Eileen R. Meehan and Ellen Riordan. Minneapolis: University of Minnesota Press, pp. 3-15.

Robb, David. 2016. MPAA: US Film and TV Industry Generates \$121 Billion in Wages. Deadline, September 2. Available online: http:/ / deadline.com/2016/09/mpaa-u-s-film-tvindustry-generates-121-billion-in-wages1201812945 / (accessed on 18 October 2018).

Robehmed, Natalie. 2016. Men Have More Lines Than Women In Disney Movies, Rom-Coms And Every Other Genre. Forbes, April 8. Available online: https:/ /www.forbes.com/sites/natalierobehmed/2016/04/08/ men-have-more-lines-than-women-in-disney-movies-rom-coms-and-every-other-genre/\#d7a64a221ee4 (accessed on 18 October 2018).

Roberts, Al. 2017. Is Google's 'Beauty and the Beast' ad the future of paid voice search? Search Engine Watch, March 23. Available online: https:/ / searchenginewatch.com/2017/03/23/is-googles-beauty-and-the-beastad-the-future-of-paid-voice-search/ (accessed on 21 April 2018).

Robinson, Joanna. 2017. Star Wars: The Last Jedi offers the harsh condemnation of mansplaining we need in 2017. Vanity Fair. December 18. Available online: https:/ / www.vanityfair.com/hollywood/2017/12/star-warslast-jedi-laura-dern-admiral-holdo-listen-to-women (accessed on 7 March 2018).

Ross, Karen, and Byerly Carolyn. 2006. Women and Media: A Critical Introduction. Malden: Blackwell.

Rowe, Karen. 1986. Feminism and Fairy Tales. In Don't Bet on the Prince: Contemporary Feminist Fairy Tales in North America. Edited by Jack Zipes. New York: Methuen, pp. 209-26.

Rysdall, Kai, and Bridget Bodnar. 2017. 'Frozen' got the new 'Beauty and the Beast' made. Marketplace, March 24. Available online: https:/ /www.marketplace.org/2017/03/24/life/what-frozen-had-do-beauty-beastreboot (accessed on 30 April 2018).

Scott, Suzanne. 2017. \#Wheresrey?: Toys, spoilers, and the gender politics of franchise paratexts. Critical Studies in Media Communication 34: 138-47. 
Sharf, Zack. 2017. The Alt-Right claims credit for ‘Star Wars: The Last Jedi' backlash. IndieWire. December 21. Available online: http:/ / www.indiewire.com/2017/12/star-wars-last-jedi-backlash-alt-right-female-characters1201910095/ (accessed on 7 March 2018).

Smith, Anna. 2017. A Force for Good: Why the Last Jedi Is the Most Triumphantly Feminist Star Wars Movie yet. The Guardian, December 18. Available online: http:/ / www.theguardian.com/film/2017/dec/18/star-warsthe-last-jedi-women-bechdel-test (accessed on 2 April 2018).

Smythe, Dallas W. 1977. Communications: Blindspot of western Marxism. Canadian Journal of Political and Social Theory 1: 1-27.

Star Wars: The Last Jedi. 2017. Rotten Tomatoes. Available online: https:/ /www.rottentomatoes.com/m/star_ wars_the_last_jedi/ (accessed on 22 April 2018).

Steeves, Leslie H., and Janet Wasko. 2002. Sex and Money: Feminism and Political Economy in the Media. Edited by Eileen R. Meehan and Ellen Riordan. Minneapolis: University of Minnesota Press, pp. 16-29.

Streiff, Madeline, and Lauren Dundes. 2017. Frozen in Time: How Disney Gender-Stereotypes Its Most Powerful Princess. Social Sciences 6: 38. [CrossRef]

Thilk, Chris. 2017. Star Wars: The Last Jedi-Marketing Recap. Cinematic Slant, December 13. Available online: https: / cinematicslant.com/2017/12/13/star-wars-the-last-jedi-marketing-recap/ (accessed on 31 May 2018).

Thomas, Ben-Beaunmont, and Phil Hoad. 2017. How We Made Beauty and the Beast. The Guardian, March 13. Available online: https:/ / www.theguardian.com/culture/2017/mar/13/how-we-made-beauty-and-thebeast (accessed on 18 October 2018).

Townsend, Matthew. 2018. Hasbro CEO Admits Making Mistake with 'Last Jedi' Toys. Bloomberg, March 29. Available online: https://www.bloomberg.com/news/articles/201803-28/hasbro-ceo-admits-making-strategic-mistake-with-last-jedi-toys?fbclid=IwAR2FiHH14f_ FD9aaQm6waOrKhBUU8yYTp60kHw4bCifqLZlqUDxu0QfZ4SQ (accessed on 18 October 2018).

Traube, Elizabeth G. 1992. Dreaming Identities: Class, Gender, and Generation in 1980s Hollywood Movies. Boulder: Westview Press.

Trujillo, Nick. 1991. Hegemonic masculinity on the mound: Media representations of Nolan Ryan and American sports culture. Critical Studies in Mass Communication 8: 290-308. [CrossRef]

Walt Disney Company. 2017. Available online: https://www.thewaltdisneycompany.com/walt-disneycompany-acquire-twenty-first-century-fox-inc-spinoff-certain-businesses-52-4-billion-stock-2/ (accessed on 5 May 2018).

Wasko, Janet. 2003. The Political Economy of Film. In A Companion to Film Theory. Edited by Toby Miller. Oxford: Blackwell Publishing, pp. 221-33.

Wasko, Janet, Eileen Meehan, and Mark Phillips. 2006. Dazzled by Disney? The Global Disney Audiences Project. New York: Bloomsbury.

Weekes, Princess. 2017. Treatment of POC \& women in Star Wars: The Last Jedi. The Mary Sue, December 22. Available online: https:/ / www.themarysue.com/poc-women-in-the-last-jedi/ (accessed on 2 April 2018).

Whitley, Jared. 2018. SJW Politics Have Handed Star Wars Its First Bomb in Solo. Daily Caller, May 29. Available online: http: / / dailycaller.com/2018/05/29/sjw-politics-solo-star-wars / (accessed on 30 May 2018).

Why the Last Jedi Isn't just Bad: It's Toxic. 2017. Scavenger's Holocron, December 22. Available online: http:/ / scavengersholocron.com/category/home/why-the-last-jedi-isnt-just-bad-its-toxic/ (accessed on 2 April 2018).

Williams, Linda. 1984. When the woman looks. In Re-Vision: Essays in Feminist Film Criticism. Edited by Mary Ann Doane, Patricia Mellencamp and Linda Williams. Los Angeles: University Publications of America, pp. 83-99.

Wosk, Julie. 2001. Women and the Machine: Representations from the Spinning Wheel to the Electronic Age. London: John Hopkins University Press.

(C) 2018 by the authors. Licensee MDPI, Basel, Switzerland. This article is an open access article distributed under the terms and conditions of the Creative Commons Attribution (CC BY) license (http:/ / creativecommons.org/licenses/by/4.0/). 